\title{
Active and Reactive Power Control for a Hybrid System with Photovoltaic Panel, Wind Turbine, Fuel Cells, Electrolyzer and Super Capacitor in Off-grid Mode
}

\author{
Omid Palizban \\ Dep. of Electrical Engineering \\ University of Malaya \\ Kuala Lumpur, Malaysia \\ omid.palizban@siswa.um.edu.my
}

\author{
M.A.Rezaei \\ Dep. of Electrical Engineering \\ Shiraz university of Technology \\ Shiraz, Iran. \\ Rezaei.mohamadamin@gmail.com
}

\author{
Saad Mekhilef \\ Dep. of Electrical Engineering \\ University of Malaya \\ Kuala Lumpur, Malaysia \\ Saad@um.edu.my
}

\begin{abstract}
This paper proposes a hybrid system which consists of a photovoltaic panel, wind turbine, proton exchange membrane fuel cell (PEMFC), electrolyzer, super capacitor, power convertor and a three-phase variation load. The load supplied is based on the photovoltaic panel and wind turbine, while the fuel cells are back-up for compensating possible power load shortage. The surplus of power produced will be stored in a hydrogen tank by an electrolyzer system when the PV panel and wind turbine produce more power than required. The capacitor banks are used in parallel with other sources in order to reduce DC bus variation. Matlab software is chosen for the hybrid system simulation.
\end{abstract}

Keywords--Electrolyzer, Fuel cell, Photovoltaic panel, Super capacitor, Wind turbine.

\section{INTRODUCTION}

Renewable energy sources are known to support system hydrogen generation. Therefore, the newly developed idea is the ability to supply the load without any compensation by the wind turbine or PV panels solus in offing. Although photovoltaic panels are used as popular renewable energy sources, two major problems they encounter depending on power production are with solar irradiation and surplus energy storage. These problems can be solved by using other renewable energy sources and storage systems such as electrolyzer, hydrogen storage tank, fuel cell, super capacitor and battery [1]. Due to high efficiency, fast response, flexibility and modular structures, a combination of super capacitor with fuel cell is the best choice for a hybrid system that uses photovoltaic panels and wind turbine. Moreover, this paper presents an IG wind turbine that does not use $\mathrm{AC} / \mathrm{DC}$ or $\mathrm{DC} / \mathrm{AC}$ converter on the IG side. Therefore, the economic justification is IG and doubly-fed induction generator (DFIG) low cost, and there is no conversion system.

\section{SYSTEM DESCRIPTION}

Fig. 1 shows system source arrangement. The proposed hybrid system has an IG wind turbine, a photovoltaic panel, fuel cell, electrolyzer system, a hydrogen storage tank and power converters. The IG wind turbine connects to the AC bus without a convertor and Photovoltaic system uses of an MPPT connected to the DC/DC converter and DC bus. The electrolyzer system as a DC load during power generation for $\mathrm{AC}$ load is higher than that of consumption. In this condition, surplus energy will be stored in a hydrogen tank after conversion to hydrogen by the electrolyzer. Moreover, the super capacitor plays the role of compensator to reduce voltage fluctuations.

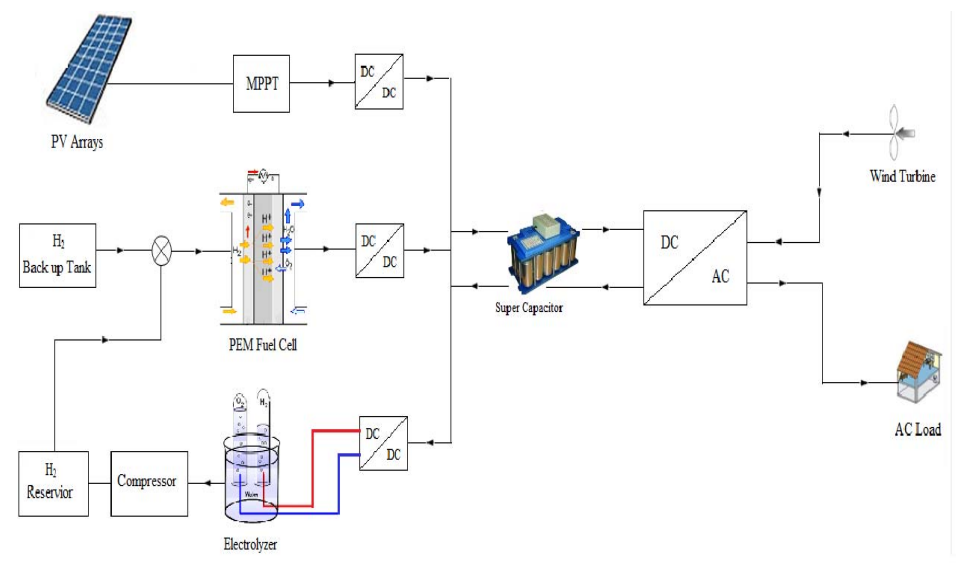

Fig.1: Block diagram of the proposed hybrid system

\section{SOURCE MODELING}

A. Photovoltaic system modeling: The simplified equivalent circuit of a PV cell, called a four-parameter circuit, is shown in Fig.2, and it consists of light current $\left(\mathrm{I}_{\mathrm{L}}\right)$, series resistance $\left(R_{S}\right)$, saturation current (Io) and thermal voltage timing completion factor $(\alpha)$ [1] [2] [3]

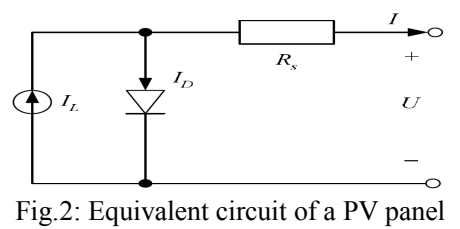


The voltage-current and current-power characteristics have the important role of receiving maximum power in photovoltaic systems. In this paper, an array of thirteen series and five parallel rows of PV is presented.Fig. 3 shows the voltagecurrent and voltage-power characteristics in a photovoltaic system [1].

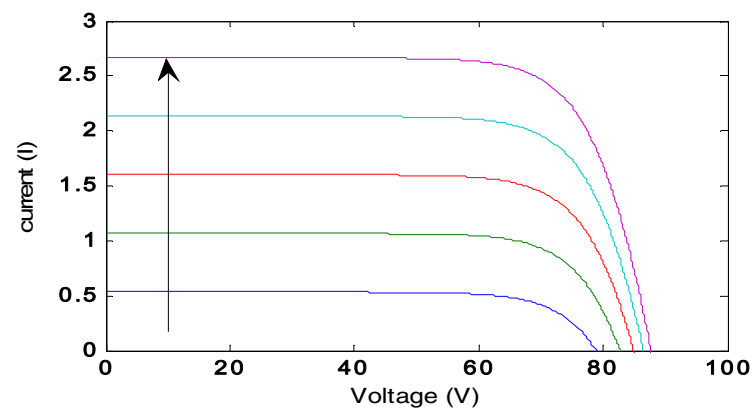

(a)

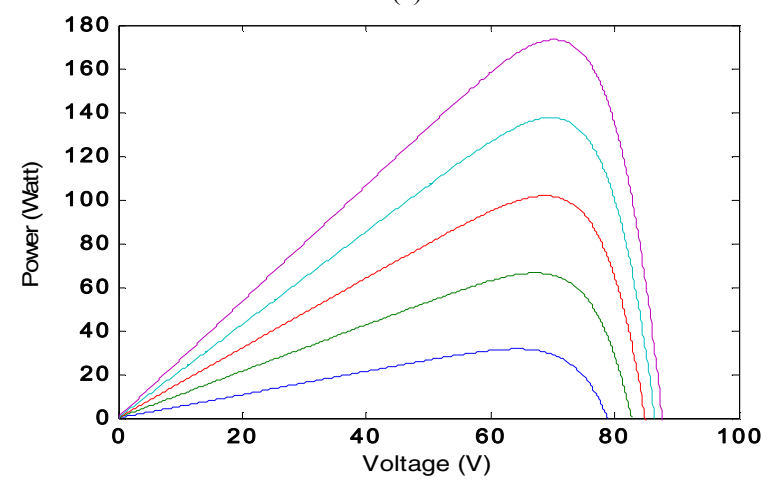

(b)

Fig.3: (a) Voltage-current (b) Voltage-power characteristics in a photovoltaic system

B. Fuel cell modeling: In the fuel cell proposed, the changing conditions are pressure, temperature, fuel cell rate and air parameters. The variations have effect on open circuit voltage $E_{o c}$ and Tafel rate current (Io), so their equations can be calculated by [4]:

$E_{o c}=E_{c} \cdot E_{n}$

$i_{o}=\frac{z f k\left(P_{H 2}+P_{o 2}\right)}{R h} e^{\frac{-\Delta G}{R T}}$

$A=\frac{R T}{Z \alpha F}$

The new values of open circuit voltage (EOC) and current $\left(\mathrm{I}_{\mathrm{O}}\right)$ can be calculated using Nerst voltage and the gas pressure values. $\Delta G, \alpha$ and $K_{c}$ parameters are also obtained based on the bipolar curve in the nominal rate with respect to the other parameters such as Low Heat Value (LHV), stack, fuel and air combination, pressure, and source temperature. In this paper $T_{d}=95 \%$ is chosen for considering double layer charging. Fig. 4 shows the fuel cell circuit schematic, which is simulated by Matlab [5] [6] [4].

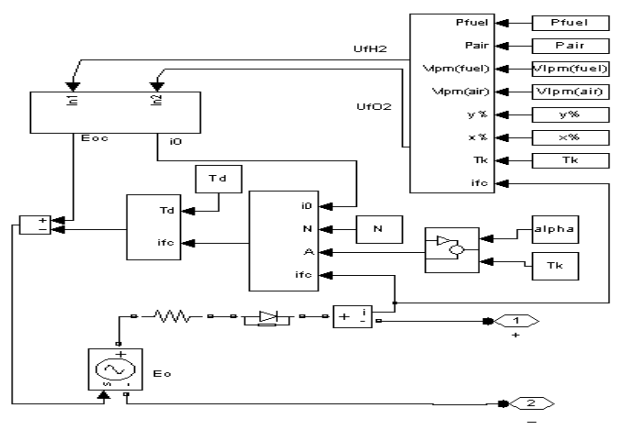

Fig.4. Fuel cell circuit schematic

C. Wind Turbine Modeling: From the different types of wind turbine, the induction generator (IG) is presented in this paper with a complete block diagram shown in Fig.5.

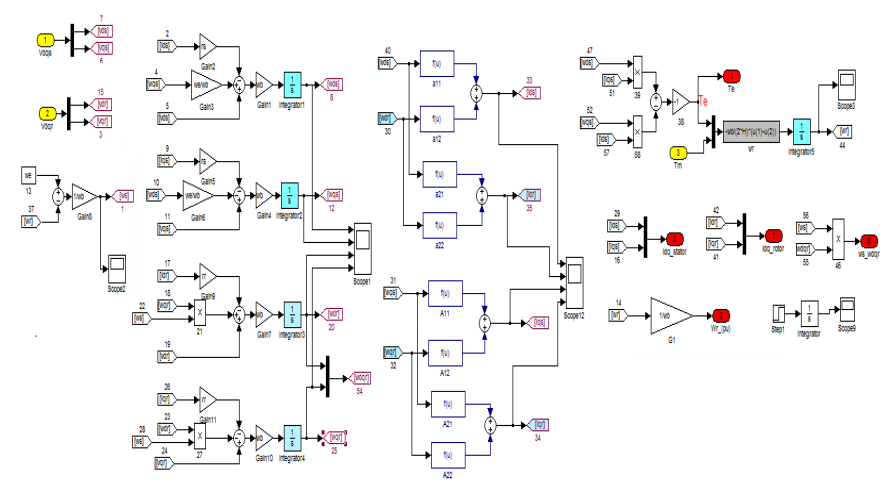

Fig.5: IG wind turbine simulation in Matlab

It should be noted that to achieve the best wind turbine performance, wind speed limitation is a requirement. Therefore, this limitation is controlled by active pitch control, and passive and active stall control [7].

D. Electrolyzer modeling: If the electricity current passes two electrodes separated by water electrolyte the result is water breaking up into hydrogen and oxygen. This process can be described as follows [8]:

$\mathrm{H}_{2} \mathrm{O}+$ Electrical Energy $=\mathrm{H}_{2}(\mathrm{~g})+\frac{1}{2} \mathrm{O}_{2}(\mathrm{~g})$

Fig.6 shows the simulated electrolyzer circuit. It should be noted that in this simulation the electrolyzer is used as a cooling system to maintain constant temperature.

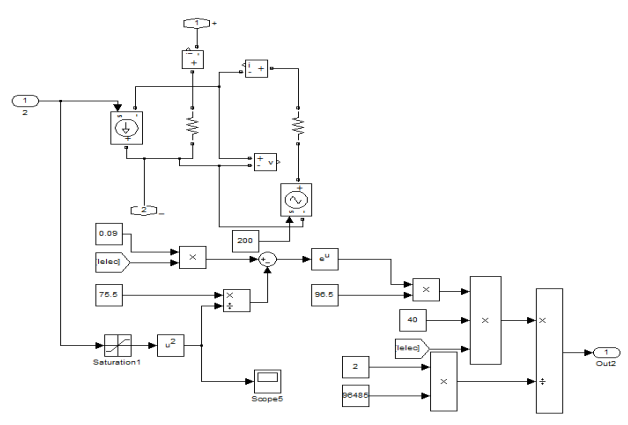

Fig.6: Electrolyzer simulation 


\section{THE POWER CONTROL STRATEGY}

The control block diagram of the hybrid system is shown in Fig.8. The maximum power produced by the solar cell, wind turbine, and fuel cell are $10 \mathrm{~kW}, 25 \mathrm{~kW}$ and $18 \mathrm{~kW}$, respectively. For more accurate and better analysis of the system, both static and dynamic investigation was performed in the 10-second and 24-hour systems.

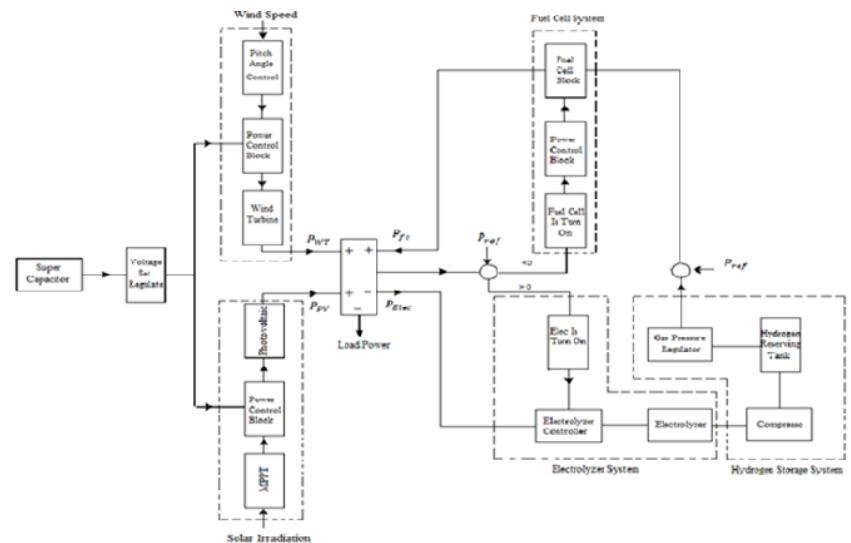

A. Static study of the system: In this paper, numerous variations in wind speed were investigated throughout a day. Moreover, the high variation in customer active and reactive power demand can be seen in Figures $9 \& 10$.

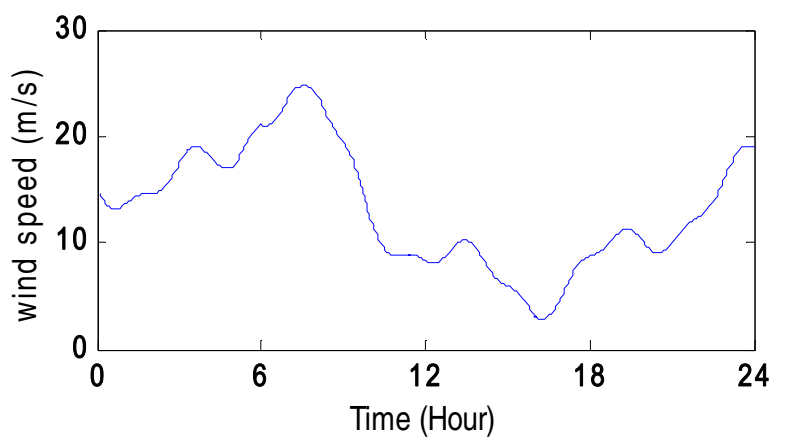

Fig.9: Wind speed variatio throughout a day

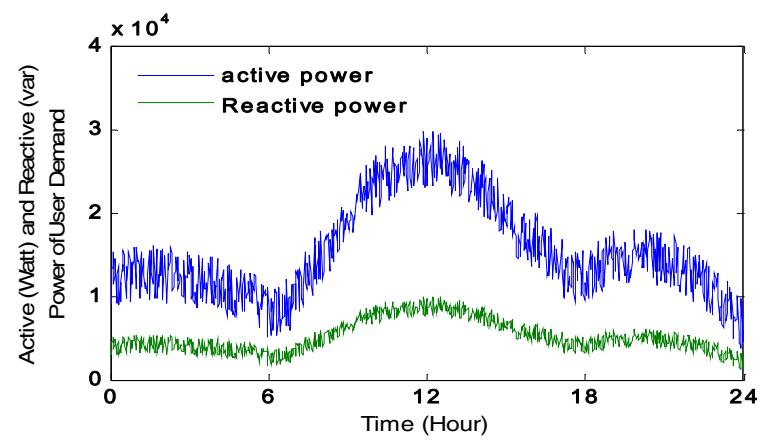

Fig.10: Active and reactive power demand

The following equation describes the main control point of the system.

$$
P_{\text {Load }}+P_{\text {elec }}=P_{w t}+P_{p v}+P_{f c}
$$

Output power variation, solar radiation, fuel cell and wind output power over 24 hours are given in Fig.11, 12, 13 \& 14, respectively. Fig. 15 and 16 display the hydrogen produced by the electrolyzer and used by the fuel cell.

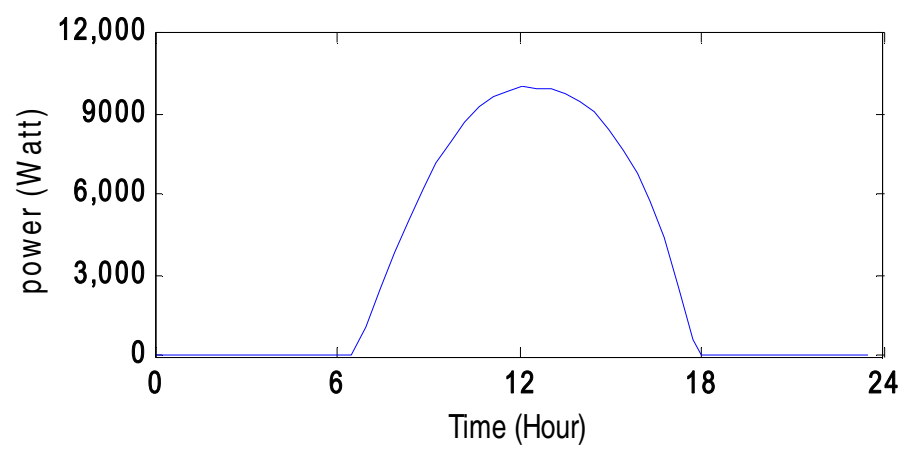

Fig.11: Output power variation in PV panel throughout a day

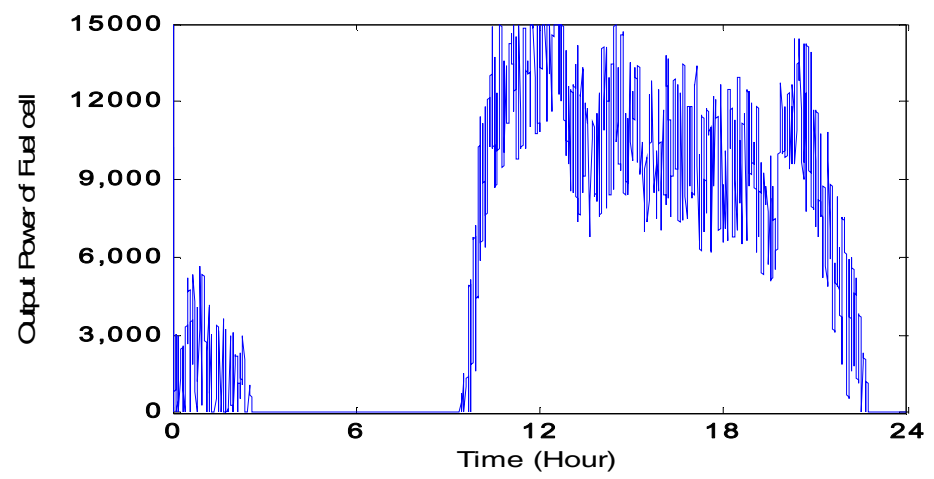

Fig.13: Fuel cell output power

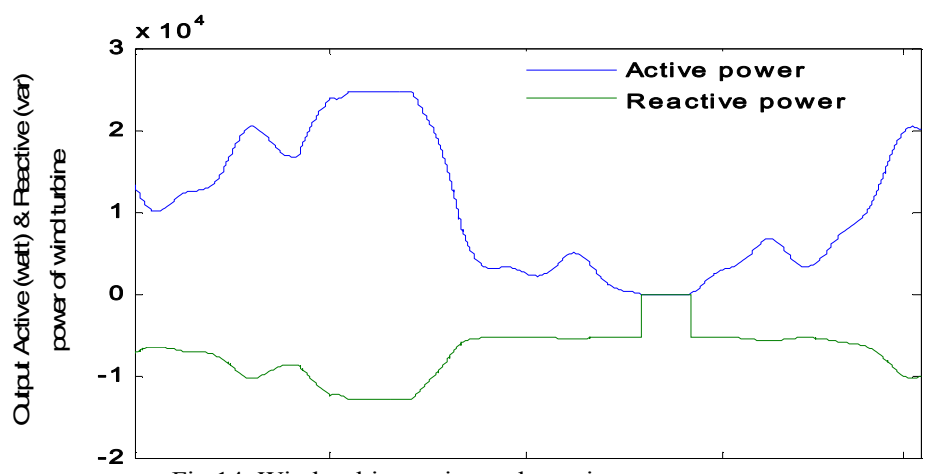

Fig.14. Wind turbine active and reactive output power

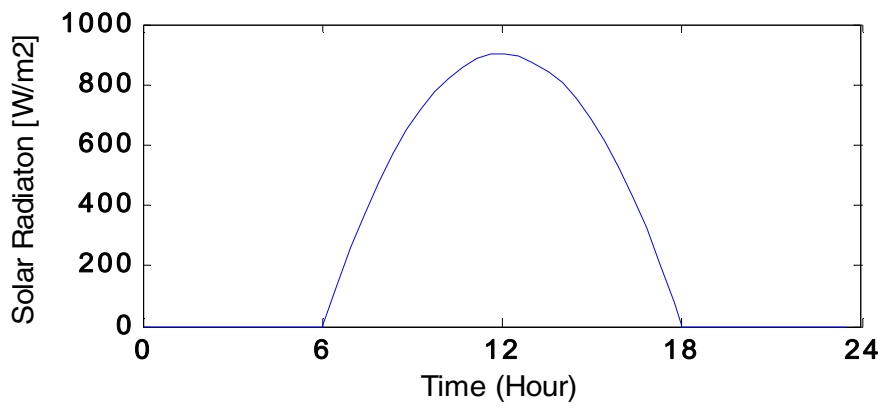

Fig .12: Solar radiation throughout a day 


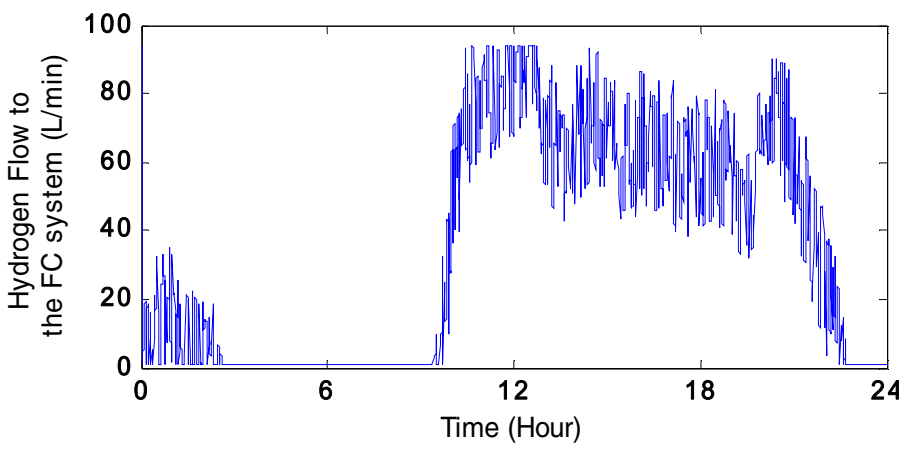

Fig.15: Hydrogen produced used by the fuel cell

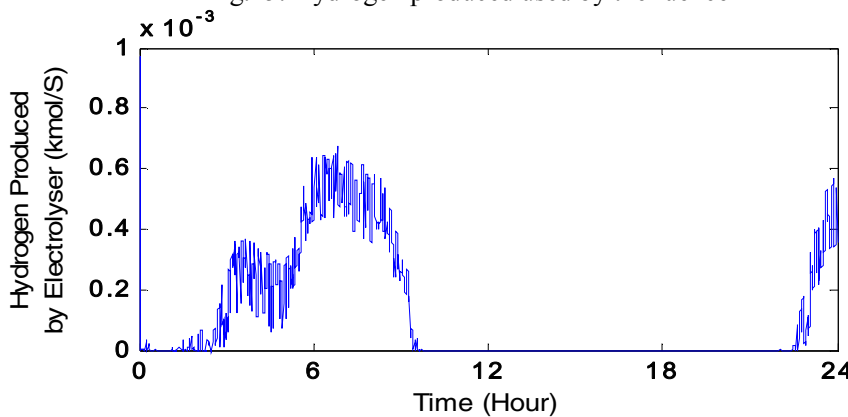

Fig.16: Hydrogen producced by the electrolyzer

1. Dynamic system study: In this part, the dynamic modes and system's response to instantaneous and steeper changes in the wind turbine and load are reviewed. As seen in the following figure, active and reactive power of load and wind change at $3-5 \mathrm{~s}$ and $2-7 \mathrm{~s}$, respectively.

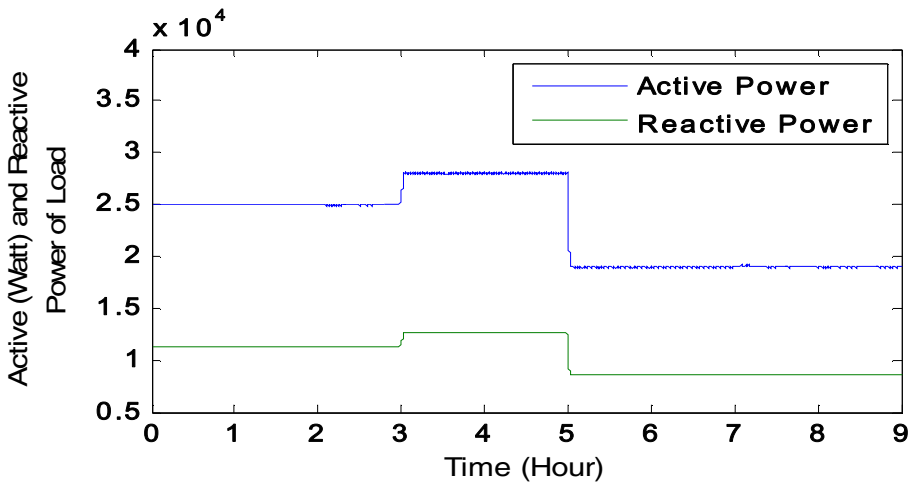

Fig.17: Active and reactive power of load

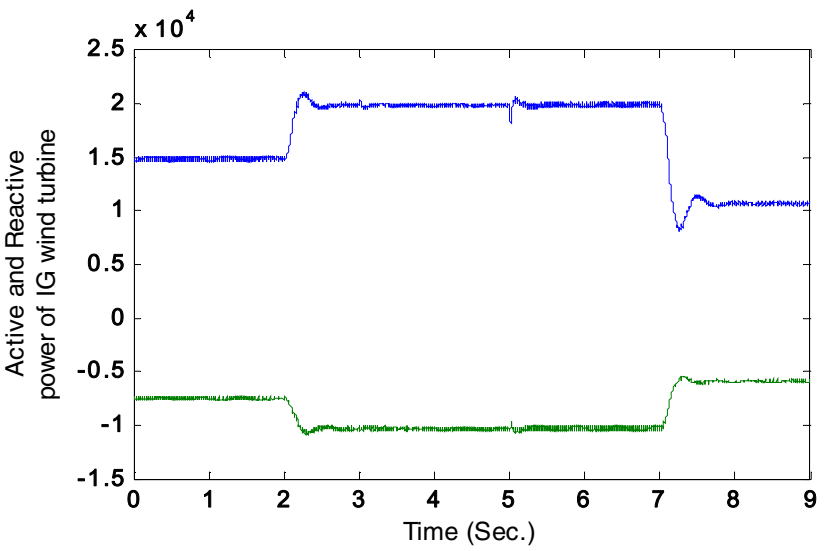

Fig.18: Active and reactive power of IG wind turbine

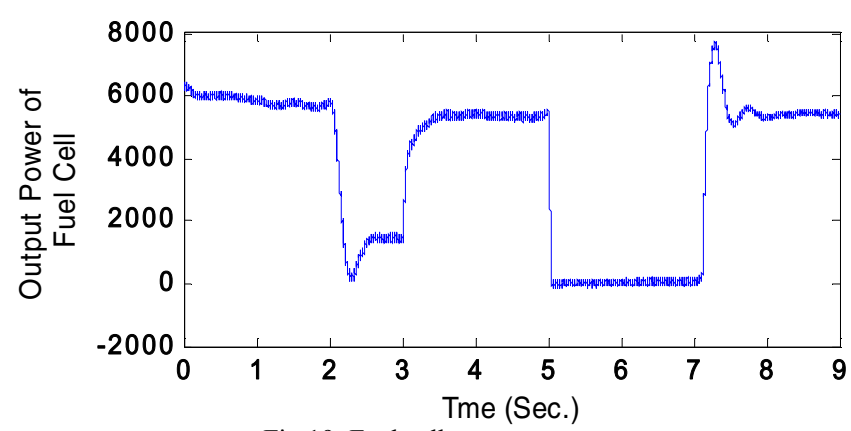

Fig.19. Fuel cell output power

Fig.20 also show the super capacitor's voltage. This figure indicates the power that the fuel cell is not able to instantly provide. Fig. 21 show solar cell output power. It is clear that solar irradiation is almost constant for 10 seconds, resulting in the creation of a constant power output during this time. From the fifth second till the seventh, power generated by the wind turbine and photovoltaic panel is more than the load demand. Therefore, fuel cell power production is zero at this time and surplus energy is used by the electrolyzer to generate hydrogen and store it in tanks (Fig. 22). Fuel cell and photovoltaic generation are injected to the inverter. The inverter output power is given in Fig.24.

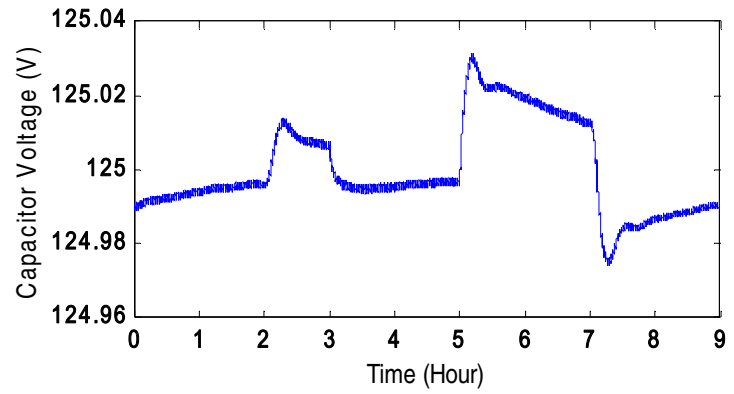

Fig.20: Super capacitor voltage

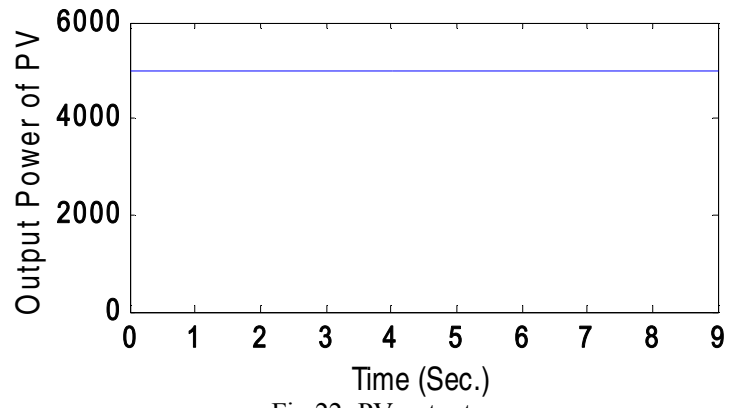

Fig.22: PV output power

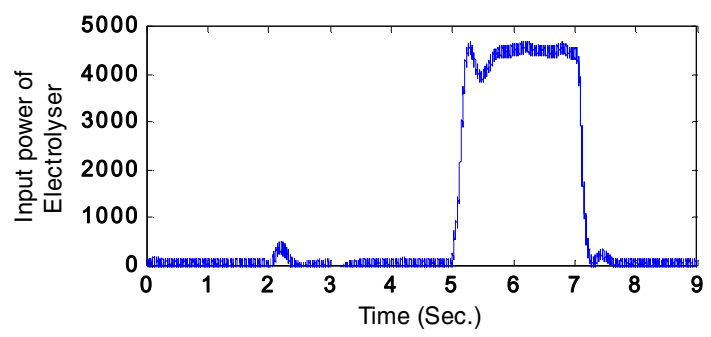

Fig.23: Electolyzer input power 


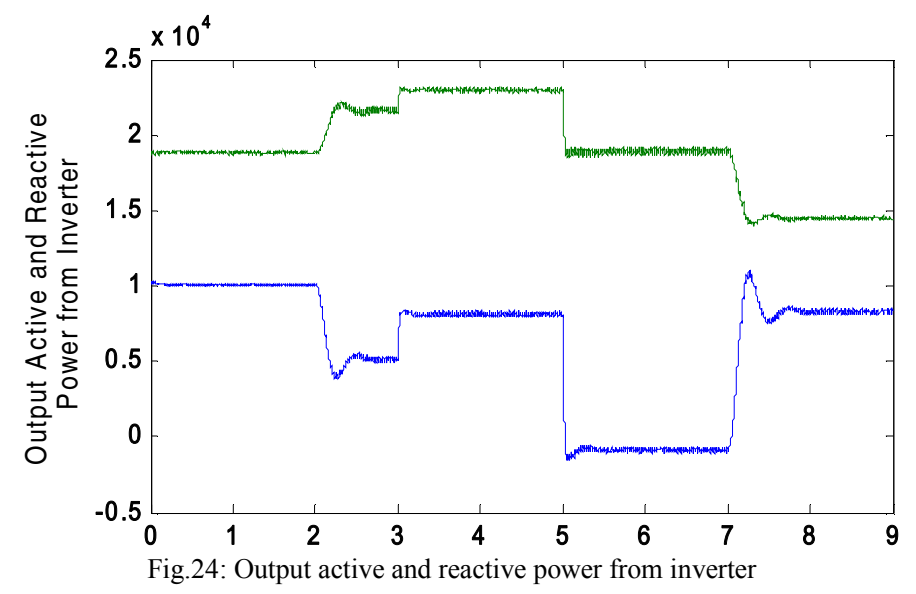

\section{CONCLUSION}

Mini grids and hybrid systems have proven their efficiency in very different applications and with various renewable energy sources. The innovations and developments from the very fast growing market for grid-connected PV technology can be applied in systems with a power range from $3 \mathrm{~kW}$ to $100 \mathrm{~kW}$ or more, and it can easily be designed, installed and operated with standard components. Since the focus of this paper was a hybrid system with renewable energy sources, Economic evaluation shows that performance has been significantly improved by the hybrid system and according to investigation hybrid systems are more efficient than using PV panels or a wind turbine alone in a system can be most important advantage of this work.

\section{Reference:}

[1] C. Wang and M. H. Nehrir, "Power management of a stand-alone wind/photovoltaic/fuel cell energy system," Energy Conversion, IEEE Transactions on, vol. 23, pp. 957-967, 2008.

[2] M. Benmessaoud, et al., "New approach modeling and a maximum power point tracker method for solar cells," Computers \& Mathematics with Applications, vol. 60, pp. 1124-1134, 2010.

[3] N. Pandiarajan and R. Muthu, "Mathematical modeling of photovoltaic module with Simulink," 2011, pp. 258-263.

[4] C. Spiegel, PEM fuel cell modeling and simulation using Matlab: Academic Press, 2008.

[5] Y. Xiao and K. Agbossou, "Interface Design and Software Development for PEM Fuel Cell Modeling Based on Matlab/Simulink Environment," 2009.

[6] K. Adzakpa, et al., "PEM fuel cells modeling and analysis through current and voltage transient behaviors," Energy Conversion, IEEE Transactions on, vol. 23, pp. 581-591, 2008.

[7] H. S. Ko, "Supervisory voltage control scheme for grid-connected wind farms," University of British Columbia, 2006.

[8] M. Uzunoglu, et al., "Modeling, control and simulation of a $P V / F C / U C$ based hybrid power generation system for stand-alone applications," Renewable Energy, vol. 34, pp. 509-520, 2009 